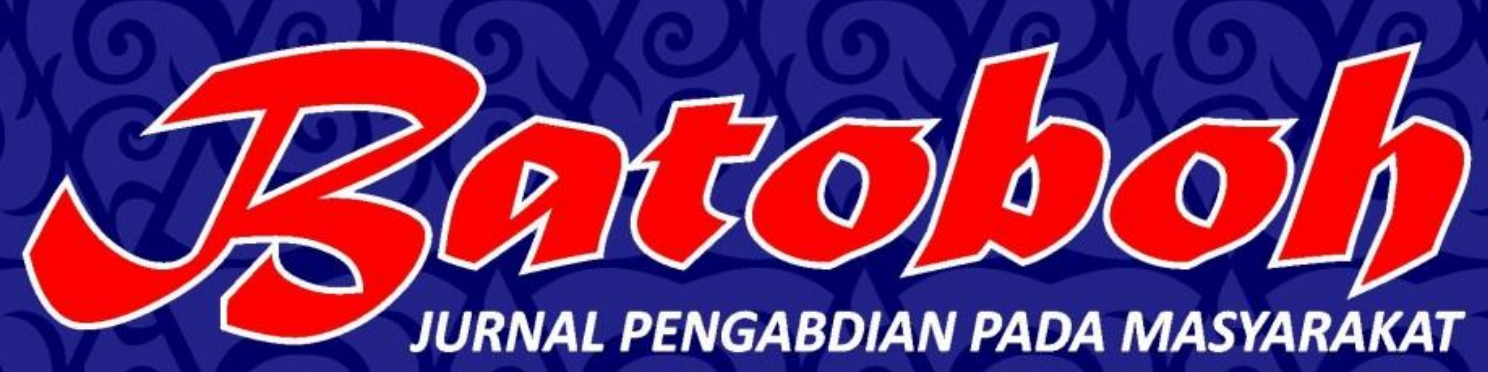

ISSN: 2548-5458

Volume 1

Nomor 2

JURNAL PENGABDIAN PADA MASYARAKAT

Oktober 2016

hlm. 131-266

Yusfil, Zulkifli, Erlinda

PENERAPAN TEKNOLOGI SENI PADA SANGGAR SENI TRADISIONAL

DI KABUPATEN PESISIR SELATAN SUMATERA BARAT

Asril

PELATIHAN LAGU SIONTONG TABANG, KURETA MANDAKI, DAN OYAK TABUIK

PADA GRUP GANDANG TASA ANAK-ANAK, SANGGAR ANAK NAGARI DESA SUNGAI PASAK, KOTA PARIAMAN

Nofrial, Wahyono, Riski Rahmat Kurniawan Dan Alek Hengki Ziora

PEMANFAATAN SERBUK GERGAJI MENJADI PRODUK KERAJINAN DI WAN PERABOT,

TARANTANG KECAMATAN HARAU, 50 KOTA

Dira Herawati, Muhammad Husni, A Nick Koto Agam, Eza Ramadhani

PELATIHAN FOTOGRAFI PADA KEGIATAN EKSTRA KURIKULER DI SMKN 2 PADANGPANJANG

F. X Yatno Karyadi, Eriswan, Bari, Rahmat, Irham

PELATIHAN PEMBUATAN VIDEO DAN FOTO MAKRO MENGGUNAKAN TABLE-TOP STUDIO UNTUK SISWA SMA

Novina Yetri Fatrina, Ediantes, Putri Andam Dewi, Suri Handai Yani

PELATIHAN TEKNIK MEMBUAT RIAS EFEK UNTUK FILM FIKSI PADA SMK 2 PADANGPANJANG

Rosta Minawati, Heri Sasongko, Gilang Febriano, Vini Rusmana

PENGENALAN PRODUKSI FILM DOKUMENTER BAGI SISWA/ SISWI SEKOLAH MENEGAH ATAS

Hafif HR, Fahmi Marh, Ade Sulistiawan, Dino Ashari

PENERAPAN MULTI DISIPLIN SENI DALAM KEGIATAN DRUMBAND PADA EKSTRAKURIKULER SMA 3 PADANGPANJANG

Febri Yulika, Selvi kasman, Putri Khairina Masta

PENINGKATAN KOMPETENSI GURU MELALUI PELATIHAN PENULISAN KARYA TULIS ILMIAH

Darmansyah, Novesar Jamarun, Firdaus, Indra Arifin, Fitra Muhaddis

PELATIHAN INSTRUMEN MUSIK TRADISIONAL MINANGKABAU DI MAN 2 GUNUNG PADANGPANJANG 



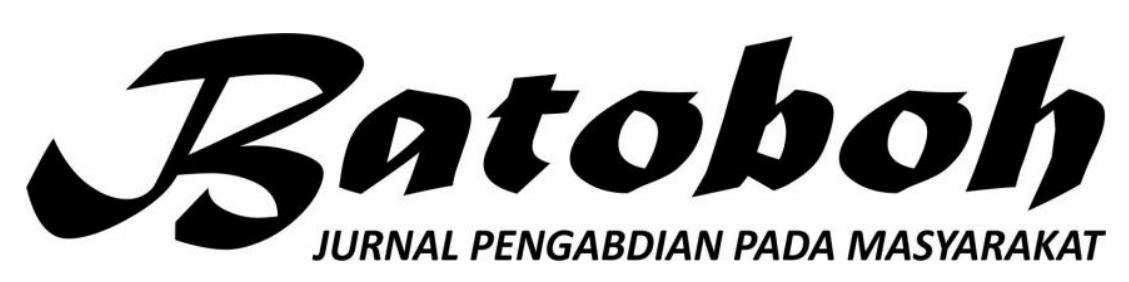

ISSN: 2548-5458 Volume 1, Nomor 2, Oktober 2016, hlm. 131-266

Terbit dua kali setahun pada bulan April dan Oktober. Pengelola Jumal Pengabdian pada Masyarakat merupakan subsistem LPPMPP Institut Seni Indonesia (ISI) Padangpanjang.

\author{
Pengarah \\ Rektor ISIPadangpanjang \\ Penanggung Jawab \\ Kepala Pusat Penerbitan ISI Padangpanjang \\ KetuaPenyunting \\ Andar Indra Sastra \\ Penyunting \\ Asril \\ Sahrul \\ RostaMinawati \\ Harissman \\ Pimpinan Redaksi \\ Saaduddin \\ Redaktur \\ Liza Asriana \\ Rori Dolayance \\ Tata Letak dan Desain Sampul \\ Yoni Sudiani \\ WebJurnal \\ Thegar Risky
}

Alamat Pengelola Jumal Batoboh:LPPMPP ISI Padangpanjang

Jalan Bahder Johan Padangpanjang 27128, Sumatera Barat; Telepon (0752) 82077 Fax. 82803;

e-mail; batoboh@gmail.com

Catatan. Isi/Materi jurnal adalah tanggung jawab Penulis.

Diterbitkan Oleh

Institut Seni Indonesia (ISI) Padangpanjang 


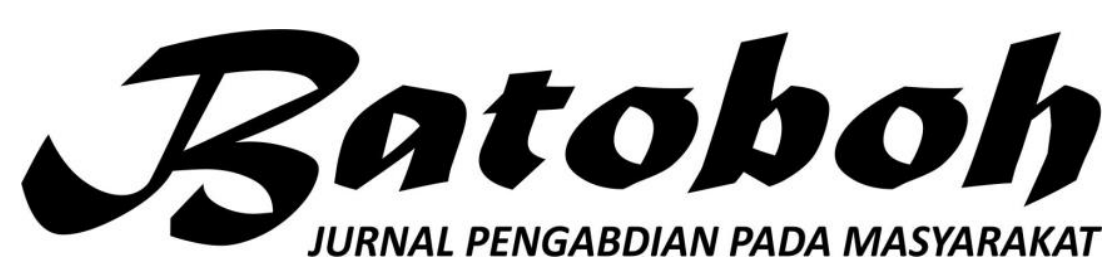

ISSN: 2548-5458 Volume 1, Nomor 2, Oktober 2016, hlm. 131-266

\section{DAFTAR ISI}

\begin{tabular}{|l|l|}
\hline \multicolumn{1}{|c|}{ PENULIS } & \multicolumn{1}{c}{ JUDUL } \\
\hline Yusfil, Zulkifli, Erlinda & $\begin{array}{l}\text { Penerapan Teknologi Seni Pada Sanggar Seni } \\
\text { Tradisional Di Kabupaten Pesisir Selatan Sumatera } \\
\text { Barat }\end{array}$ \\
Asril & $\begin{array}{l}\text { Pelatihan Lagu Siontong Tabang, Kureta Mandaki, } \\
\text { Dan Oyak Tabuik Pada Grup Gandang Tasa Anak- } \\
\text { Anak, Sanggar Anak Nagari Desa Sungai Pasak, } \\
\text { Kota Pariaman }\end{array}$ \\
$\begin{array}{l}\text { Nofrial, Wahyono, Riski } \\
\text { Rahmat Kurniawan Dan } \\
\text { Alek Hengki Ziora }\end{array}$ & $\begin{array}{l}\text { Pemanfaatan Serbuk Gergaji Menjadi Produk } \\
\text { Kerajinan Di Wan Perabot, Tarantang Kecamatan } \\
\text { Harau, 50 Kota }\end{array}$ \\
\hline
\end{tabular}

HALAMAN

Dira Herawati,

Muhammad Husni, A

Nick Koto Agam, Eza

Ramadhani

F. X Yatno Karyadi,

Pelatihan Fotografi Pada Kegiatan Ekstra

Kurikuler Di SMKN 2 Padangpanjang

131-144

$145-164$

Eriswan, Bari, Rahmat, Irham

Novina Yetri Fatrina, Ediantes, Putri Andam Dewi, Suri Handai Yani

Pelatihan Pembuatan Video Dan Foto Makro

190-200 Menggunakan Table-Top Studio Untuk Siswa SMA

Pelatihan Teknik Membuat Rias Efek Untuk Film 201-212 Fiksi Pada SMK 2 Padangpanjang

Rosta Minawati, Heri Sasongko, Gilang

Pengenalan Produksi Film Dokumenter Bagi $213-227$ Febriano, Vini Rusmana

Hafif HR, Fahmi Marh, Ade Sulistiawan, Dino Ashari Siswa/Siswi Sekolah Menegah Atas

$165-181$ 182-189

Febri Yulika, Selvi Kasman, Putri Khairina Masta

Darmansyah, Novesar Jamarun, Firdaus' Indra Arifin, Fitra Muhaddis

Penerapan Multi Disiplin Seni Dalam Kegiatan Drumband Pada Ekstrakurikuler SMA 3 Padangpanjang

Peningkatan Kompetensi Guru Melalui Pelatihan Penulisan Karya Tulis Ilmiah

Pelatihan Instrumen Musik Tradisional $256-266$ Minangkabau Di MAN 2 Gunung Padangpanjang

\footnotetext{
Peraturan Direktur Jenderal Pendidikan Tinggi Kementerian Pendidikan Kebudayaan Republik Indonesia Nomor 1 Tahun 2014 Tanggal Tentang Pedoman Akreditasi Terbitan Berkala Ilmiah. Jumal Batoboh Terbitan Vol. 1, April dan Oktober 2016 Memakaikan Pedoman Akreditasi Berkala Ilmiah Tersebut.
} 



\title{
PELATIHAN FOTOGRAFI PADA KEGIATAN EKSTRA KURIKULER DI SMKN 2 PADANGPANJANG
}

\author{
Dira Herawati, Muhammad Husni, A Nick Koto Agam, Eza Ramadhani \\ Prodi Fotografi \\ Fakultas Seni Rupa dan Disain- ISI Padangpanjang. \\ Jl. Bahder Johan, Padangpanjang, Sumatra Barat
}

\begin{abstract}
ABSTRAK
Program pengabdian Pelatihan Fotografi pada Kegiatan Ekstra Kurikuler di SMKN 2 di Padangpanjang ini. Pelatihan di lakukan dengan beberapan tahapan, dimulai dari pengetahuan tentang teknik dasar fotografi, tentang pencahayaan dalam fotografi. Tahap berikutnya penjelasan beberapa genre dalam fotografi, serta beberapa komposisi dalam fotografi dan juga contoh-contoh foto yang meliputi penjelasan tentang komposisi itu sendiri.Tujuan dari pelatihan fotografi ini adalah memberikan pemahaman tentang fotografi digital terhadap siswa dan juga mengajarkan dan mengajak siswa untuk bisa mengaplikasikan teknologi digital dalam dunia fotografi. Secara khusus tujuan pengabdian ini juga memberikan sebuah pola yang lebih simple dalam proses memotret sehingga membuat proses menjadi lebih cepat dan memberikan tip dan baik bagaimana caranya membuat hasil foto menjadi lebih menarik danmemberikan pelatihan agar foto yang dihasilkan bernilai seni tinggi.Metode yang digunakan dalam pelatihan ini adalah metode ceramah yaitu menyampaikan materi, mulai dari teknik dalam fotografi. Bedah karya foto, mengkoreksi foto di photoshop kemudian hasil akhir membuat sebuah pameran.
\end{abstract}

Kata kunci: pelatihan fotografi, pameran 


\section{PENDAHULUAN}

Zaman sekarang dikenal
dengan zaman serba canggih atau
sering disebut dengan zaman digital.
Zaman digital adalah satu era dimana
semua bisa dilakukan dengan cepat dan
canggih berbasis teknoligi kekinian. Pada pemanfaatan teknologi digital semua terasa gampang dan seolah-olah tidak punya banyak tantangan. Semua terjadi karena pada zaman serba digital ini apapun kebutuhan manusia dapat diakses oleh siapapun dengan cepat dan tidak membutuhkan waktu yang lama, seperti yang pernah dirasakan pada sistim manual atau lebih tepatnya sistem konvensional.

Zaman digital membawa manusia pada keefektifan pola kerja dan bisa menyederhanakan banyak hal, membuat proses jadi lebih simple dan lebih menghemat waktu, tenaga dan biaya. Selain dari keuntungan dan manfaat positif dari zaman digital yang telah diuraikan diatas, ternyata proses digital tidak selalu mendatangkan keuntungan dan berakibat positif, pada beberapa sisi proses digital justru membuat manusia kurang menghargai proses karena semua dianggap bisa dilakukan dengan gampang, selain dari menganggap pekerjaan bisa dilakukan dengan gampang, proses digital juga membuat hakikat dan nilai dari sesuatu itu jadi lebih tidak bermakna disbanding dengan teknologi biasa atau manual.

Ada banyak bentuk teknologi digital yang sudah ikut membantu proses pekerjaan dan kehidupan manusia, salah satu diantaranya adalah teknologi dalam dunia fotografi, dalam dunia fotografi ada banyak pemanfaatan teknologi digital, baik yang bersifat hardware seperti kamera atau beberapa alat bantu lainnya maupun yang bersifat software seperti aplikasi dan software dalam proses mengolah foto menjadi lebih menarik atau menjadi lebih gampang dalam pengerjaannya.

Berbeda dengan fotografi pada era manual, yang masih memakai film sebagai salah satu media dalam penyimpanan hasil jepretan dan kamera dengan fasilitas manual yang menyebabkan hasil bidikan gambar kamera tidak bisa dikatahui sebelum dicetak terlebih dahulu di foto studio atau tempat pencetakan foto, Pemanfaatan teknologi digital dalam 
dunia fotografi membuat proses Hand Phone, Monitor pada Laptop, memotret menjadi jauh lebih gampang, Pen Cam, dan munculnya kamera orang bisa mengetahui bagaimana hasil digital yang sangat membantu dalam bidikannya langsung setelah dia kemudahan proses memotret. Selain melakukan pemotretan, dan pada era tidak membutuhkan film roll, kamera teknolgi digital ini seorang fotografer digital juga menguntungkan dalam bisa mengatur dan mensiasati proses memantau atau me review hasil bagaimana hasil fotonya nantinya jepretan.

sesuai dengan apa yang dia inginkan, pengaturan dan perencanaan hasil foto iti bisa dilakukan bahkan sebelum memulai melakukaan pemotretan, hal ini membuat hasil fotografi digital terasa tidak sulit dan bukanlah sesuatu yang bernilai istimewa, karena foto dapat dibuat dengan cepat, mudah dan hasil bisa diatur sesuai dengan keinginan.

Proses memotret dalam teknologi Fotografi digital dapat dilakukan dengan berbagai macam cara, dan berbagai macam alat, kalau pada zaman dahulu saat fotografi masih manual, orang mesti memotret dengan kamera yang diisikan film roll kedalamnya untuk menyimpan hasil jepretan. Teknologi digital justru menyajikan hal yang menarik, sehingga kamera manual tidak lagi terlalu dibutuhkan, banyak alat yang bisa dijadikan sebagi kamera, seperti Banyak manusia pada zaman sekarang yang menjadi penyuka dunia fotografi karena hadirnya teknologi digital ini. Para penikmat dunia fotografi ataupun para pelaku atau yang biasa disebut dengan fotografer bermunculan dimana-mana, bahkan pada zaman sekarang rasanya sebuah peristiwa tidak akan menarik kalau tidak diabadikan dulu dengan kamera digital yang mereka punya, semua peristiwa yang terjadi baik itu peristiwa penting dan serius seperti acara formal maupun hal-hal sepele seperti berfoto sebelum makan pun tidak luput dari proses diabadikan dengan kamerakamera yang sangat banyak dan gampang untuk diakses.

Beranjak dari fenomena diatas, penulis sekaligus calon pelatih dalam pengabdian ini ingin mengadakan sebuah pelatihan fotografi digital, yang akan menjadi mitra pelatihan yang 
ditargetkan adalah siswa SMKN 2 Padangpanjang, pemilihan mitra SMKN 2 dikarenakan, disekolah ini ada banyak kegiatan ektra kurikuler yang bersifat mengembangkan bakat siswa terutama yang bernuansa karya seni, seperti salah satunya adalah Fotografi. Alasan kedua memilih SMKN 2 adalah karena pada zaman sekarang hampir semua orang suka memotret dan suka jadi objek foto, akan tetapi tidak semua orang yang sepenuhnya faham tentang bagaimana memanfaatkan media foto digital untuk menghasilkan foto yang lebih menarik dan punya nilai estetika yang bagus.

Melalui pelatihan fotografi digital ini, penulis ingin memberikan sebuah kemampuan memotret terhadap siswa SMKN 2 Padangpanjang, sehingga hasil karya foto mereka selama ini menjadi jauh lebih baik dan lebih bernilai seni dibanding yang sudah ada selama ini.

\section{B. PELATIHAN FOTOGRAFI}

\section{Target}

a. Memberikan pemahaman tentang fotografi digital terhadap siswa b. Mengajarkan dan mengajak siswa untuk bisa mengaplikasikan teknologi digital dalam dunia fotografi

c. Memberikan sebuah pola yang lebih simple dalam proses memotret sehingga membuiat proses menjadi lebih cepat

d. Memberikan tip dan trik bagaimana caranya membuat hasil foto menjadi lebih menarik

e. Memberikan pelatihan agar foto yang dihasilkan bernilai seni tinggi

2. Luaran

a. Karya Fotografi yang bernilai seni tinggi.

b. Pameran Hasil Hunting Fotografi.

Pelatihan Fotografi pada Kegiatan Ekstra Kurikuler di SMKN 2 Padangpanjang mengunakan metode ceramah, diskusi, Demonstrasi dan praktek langsung. Adapun tahapannya sebagai berikut :

1. Pemaparan mengenai tehnik dasar fotografi.

2. Materi tentang Komposisi dan genre dalam fotografi. 
3. Pemaparan kiat-kiat khusus untuk menghasilkan karya fotografi yang menarik dan bernilai seni.

4. Mendemontrasikan tehnik pengambilan foto/ gambar.

5. Hunting bersama

6. Bedah karya foto hasil hunting.

7. Memberikan materi edit photo dengan Photoshop.

8. Pameran hasil fotografi.

Hasil yang telah dicapai dalam rangkaian pengabdian dari tanggal 22 Juli sampai 09 September 2016 di SMKN 2 Padangpanjang adalah sebagai berikut :

1. Pemberian materi tentang tehnik dasar Fotografi ( Tentang kamera dan Lensa, Pencahayaan, kecepatan rana, bukaan diafragma) dan Komposisi Fotografi (Komposisi Statis dan Komposisi Dinamis). Berlangsung selama 4 kali pertemuan (22 Juni s.d 12 Agustus 2016). Dengan pemberian materi ini diharapkan siswa memahami tehnik dasar dalam bidang fotografi.

2. Pertemuan tanggal 19 dan 26 Agustus dilakukan demonstrasi penggunaan kamera DSLR dan hunting bersama, dengan kegiatan ini diharapkan siswa dapat mengaplikasikan semua materi yang telah diberikan sebelumnya.

3. Pertemuan tanggal 02 dan 09 September dilakukan kegiatan diskusi bersama, membahas hasil foto yang diambil siswa pada saat kegiatan hunting foto bersama.

Pemberian materi tentang teknik fotografi pada siswa SMKN 2 Padangpanjangdi lakukan sebanyak 3 kali pertemuan. Siswa aktif bertanya selama pemberian materi tersebut, ada istilah-istilah dalam fotografi yang kadang siswa belum paham. Seperti seharusnya pengambilan gambar dalam sebuah foto juga harus meliputi estetik selain dari segi teknik. Fotografi juga harus mengandung unsur bahwa foto itu mewakili jiwa si fotografernya. Foto yang menarik adalah foto yang bisa berbicara, jadi selama ini siswa hanya mengerti tentang teknik, tetapi foto yang berbicara seperti apa mereka belum mengerti.

Proses fotografi adalah di seputar membingkai foto dengan mengatur elemen visual untuk hasil yang maksimal. Dengan pengalaman mengamati jendela bidik, melihat penempatan garis dan bentuk, 
keseimbangan, hubungan background dan foreground. Banyak hal yang harus di perhatikan bagi seorang fotografer, yaitu masalah pencahayaan selain masalah teknik dan komposisi. Untuk itu dengan pelatihan ini siswa di harapkan lebih mengerti elemenelemen penting dalam fotografi.

Setelah 3 kali pemberian materi siswa di ajak langsung untuk mempraktekkan apa yang telah di berikan, untuk itu di pilihlah lokasi Danau Singkarak. Pemilihan lokasi ini dikarenakan disana terdapat landscape dan juga human interest jadi banyak objek yang akan mereka bidik. Ketika mereka berangkat untuk hunting cuaca sedang mendung tapi tidak menyurutkan semangat para siswa untuk tetap mengambil gambar disekitaran Danau Singkarak.

Karena begitu antusiasnya para siswa anggota bertambah menjadi 8 siswa, mereka ditantang untuk bisa menentukan objek yang menarik, komposisi yang baik dan teknik yang tepat. Siswa diharuskan memilih satu subjek yang sama tetapi dengan komposisi yang berbeda-beda. Latihan ini akan merenggangkan otot-otot visual dan membuat lebih mudah untuk mencoba sudut pandang lain di pemotretan berikutnya.

Latihan ini akan membuat siswa memotret dan bergerak lebih banyak, dan akan membantu siswa untuk mencapai langkah selanjutnya untuk menjadi fotografer yang hebat. Proses mengambil gambar atau Hunting pun membutuhkan fisik yang baik dan juga harus peka terhadap objek yang ada di sekitar kita, bahkan siswa juga harus tahu bahwa kita boleh keluar dari zona nyaman dalam berkreatifitas terutama di bidang fotografi.

\section{KESIMPULAN}

Kegiatan Pelatihan Fotografi pada Kegiatan Ekstra Kurikuler di SMKN 2 Padangpanjang telah berjalan sebanyak 8 kali pertemuan. Kegiatan berlangsung di SMKN 2 Padangpanjang tanpa mengalami kesulitan yang berarti. Walau diikuti hanya 4 siswa dai target yang ingin di capai tetapi antusias dari empat orang siswa yang mengambil bidang fotografi sebagai kegiatan ekstrakurikuler juga sangat bagus.

Tetapi pada saat hunting bersama ada penambahan siswa 3 
orang, itu menandakan antusiasnya siswa dalam bidang fotografi.Kegiatan pengabdian telah sampai pada tahap bedah karya hasil hunting foto bersama. Pertemuan selanjutnya pemberian materi editing foto dan persiapan pameran hasil karya fotografi siswa.

\section{FOTO KEGIATAN}

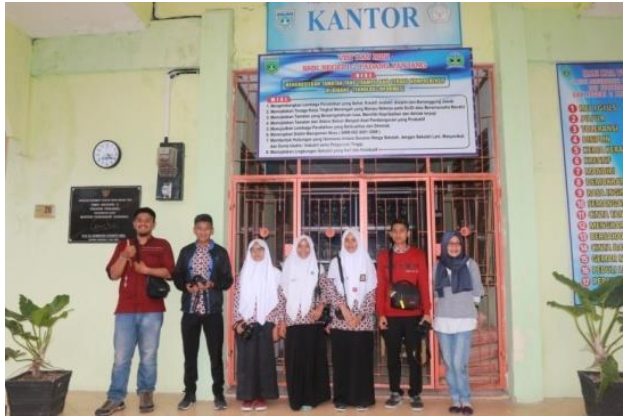

Gambar 1.

Bersama perwakilan Peserta Pengabdian (Foto: Husni, 2016)

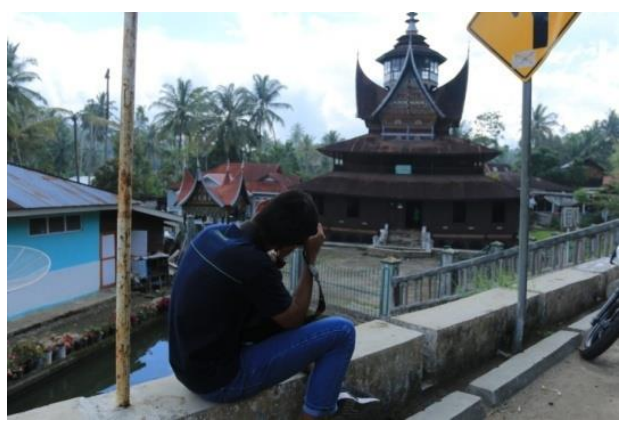

Gambar 2.

Peserta Pengabdian mengambil objek fotografi (Foto: Husni, 2016)

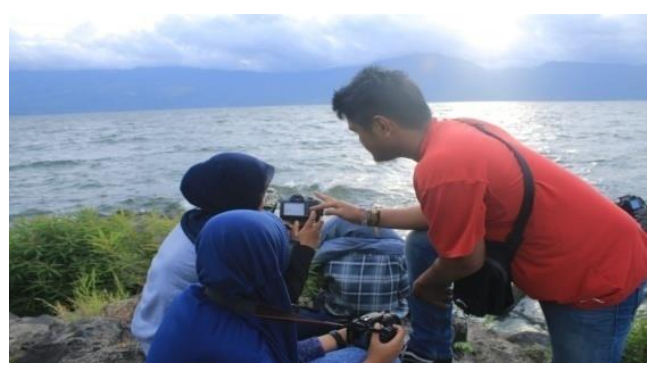

Gambar 3.

Peserta Pengabdian mengambil objek fotografi (Foto: Husni, 2016)

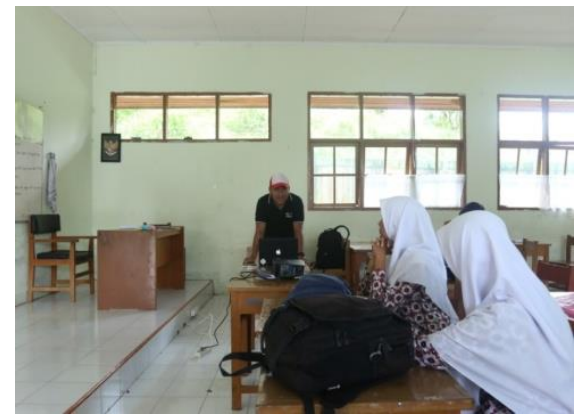

Gambar 4.

Memberikan pengarahan tentang objek fotografi

(Foto: Husni, 2016)

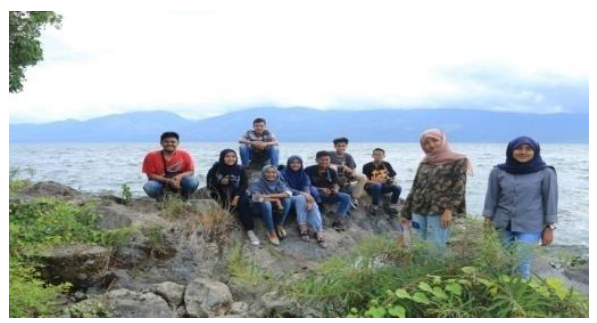

Gambar 5.

Bersama peserta pengabdian di lapangan (Foto: Husni, 2016)

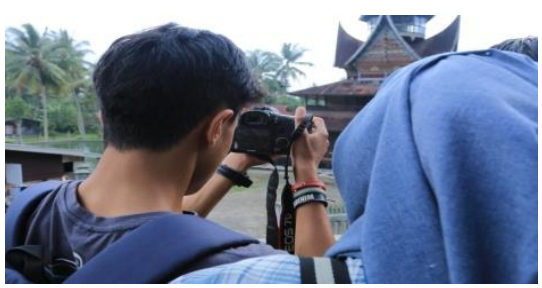

Gambar 6.

Bersama peserta pengabdian melatihakn objek fotografi

(Foto: Husni, 2016) 


\section{KEPUSTAKAAN}

Ardiyansyah Yulian, 2005, Tips dan Trik, Jakarta : Grasindo

Garvey Richard-Williams, 2015, Mastering Composition, Jakarta : PT. Gramedia

Soekojo, Makarios. 2007, Dasar Fotografi Digital, Jakarta: PT Prima Infosarana

Sugiarto, Atok. 2013, Kamera Digital Untuk Pemula, Jakarta : Erlangga
2014, Seni Digital Membuat Foto Tanpa Kamera, Jakarta : Elex Media Komputindo

Sadono, Sri. 2012, FotoMaster Teknik Dasar Fotografi Digital, Jakarta : RanaKata

Simon, Steve.2013, The Passionate Photographer, Jakarta : Elex Media Komputindo 
FILOSOFI "BATOBOH": Dalam masyarakat Minangkabau upacara-upacara yang dilakukan sebelum mendirikan bangunan baik Rumah Gadang maupun Balairung (Balai Adat) serta bangunan lainnya yang dikenal dengan beberapa upacara yang disebut dengan batoboh. Batoboh berasal dari kata Taboh yang artinya menebang atau mengambil sesuatu, jadi dengan mengambil kayu dihutan sebagai bahan utama dalam membangun rumah dan bangunan lainnya. Upacara Batoboh ini sangat bermanfaat bagi masyarakat Minangkabau yaitu dapat meningkatkan Gotong-Royong dan solidaritas antar sesama suku Minangkabau karena memberi kesempatan kepada kerabat-kerabat untuk terlibat dalam pembangunan rumah serta bangunan lain.

Alamat Redaksi: LPPMPP ISI Padangpanjang Jalan Bahder Johan Padangpanjang 27128 Sumatera Barat Telp. (0752) 485466, Fax.(0752) 82803 e-mail: batoboh@gmail.com

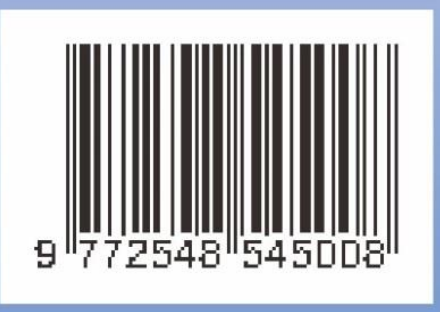

